\title{
Water Hardness Removal for Industrial Use: Application of the Electrolysis Process
}

\author{
Agostinho $\mathrm{LCL}^{1 *}$, Nascimento $\mathrm{L}^{2}$ and Cavalcanti $B F^{3}$ \\ ${ }^{1}$ Chemistry Department-CD/CST-UEPB, Rua Juvêncio Arruda, s/n-Bodocongó-CEP: Campina Grande, Paraiba, Brazil \\ ${ }^{2}$ Civil Engineering Department-CED/UNIPÊ, Campus do UNIPÊ/BR-230-Km 22, Bloco-F, Água Frio-CEP: Joao Pessoa, Paraiba, Brazil \\ ${ }^{3}$ Civil Engineering Academic Unity-CEAU/CTNR-UFCG, Av. Aprígio Veloso, 882-Bloco CQ-CEP: 58. 429-900, Campina Grande, Paraiba, Brazil
}

\begin{abstract}
Lime-soda softening for treating very hard waters is generally applied as a conventional water treatment process for municipal use. However, for industrial use, this treatment is not applied because: (a) it requires a long detention time for magnesium and calcium precipitation (about 4, 5 hours); (b) a supersaturation associated with an hexahydrate $\mathrm{CaCO}_{3}$ formation can be accomplished leading to severe incrustation of conduits and (c) a post stabilization of final water is needed. This paper addresses a study on the performance of the electrolysis process applied "per se" and with alkaline chemical dosing for removal of noncarbonated hardness for industrial use. The water used in experiments was the tap water of the reticulation system of Campina Grande in Paraiba state, Brazil. Results showed that the production of primary coagulant during electrolysis improved flotation of both calcite (calcium carbonate, $\mathrm{CaCO}_{3}$ ) and magnesium hydroxide, $\mathrm{Mg}(\mathrm{OH})_{2}$. The overall removal rate obtained with this process was $80 \%$ with a detention time of 40 minutes which is about $17 \%$ of the time needed in conventional Water Treatment Plants.
\end{abstract}

Keywords: Noncarbonated hardness removal; Electrolysis process; Chemical dosing

\section{Introduction}

Lime-soda softening is generally applied in waters with high concentrations of dissolved solids such as high calcium and magnesium species and also for some ironed species water. In this process, at $\mathrm{pH}$ around 11.00 and after hydroxyl ions addition, magnesium ions are precipitated as solid magnesium hydroxide, $\mathrm{Mg}(\mathrm{OH})_{2}$. The hydroxyl ions added are lime, $\mathrm{CaO}$ or calcium hydroxide, $\mathrm{Ca}(\mathrm{OH})_{2}$. Calcium reduction is achieved by adding sodium carbonate or soda, $\mathrm{Na}_{2} \mathrm{CO}_{3}$ to the slurry of precipitate until calcium concentration reaches a prefixed value. Generally, it is adjusted for potable use of water, a calcium concentration of $60 \mathrm{mg} / \mathrm{L} \mathrm{CaCO}_{3}$ and for magnesium a maximum value of $5 \mathrm{mg} / \mathrm{L} \mathrm{CaCO}_{3}$.

Lime-soda process was applied by Cavalcanti and Bonifacio [1] to the blend "raw water, rw":"aerated water, aw" in samples from the Water Treatment Plant, WTP at Gravatá, Paraiba State, Brazil. The mixing channel where the samples were taken was placed prior the following processes: sedimentation, filtration and disinfection. The results showed a final $\mathrm{pH}$ value of about 11.07 which was inadequate for general distribution. Another disadvantage of this process is that it requires a long detention time (above eight hours) in the sedimentation tank in order to precipitate total alkalinity and calcium carbonate, $\mathrm{CaCO}_{3}$.

According to Agostinho et al. [2] the process of electrolysis has been used for removing impurities from a variety of domestic wastewater, eutrophic waters and industrial wastes. In water treatment, electrolysis can be defined as a combination of the processes of coagulation, flocculation, flotation and disinfection. The observed effects are various such as: destabilization of colloids (for color removal), rapid flocculation with material eroded electrodes, and electrochemical reactions redox with the removal of various industrial pollutants such as heavy metals, rust faster and stronger among others. The electrolysis also allows chloride is naturally present in dissolved form in the raw water produces chloride ions and other antibacterial substances improving the disinfection process.
As the water treatment process, electrolysis of water produces two types: (1) alkaline water is reduced and (2) acidic water and oxidized. In the anode, water is oxidized when the metal electrode is placed in solution. There by releasing electrons in the metal, the $\mathrm{pH}$ decreases $(\mathrm{pH}<3.0)$ and the water becomes acidic and low in dissolved oxygen. At the cathode, the alkalinity is reduced and water is established by increasing the hydroxyl ion, $\mathrm{OH}^{-}$which contributes to the increase of $\mathrm{pH}$; namely:

$$
2 \mathrm{H}_{2} \mathrm{O}+2 e^{-} \rightarrow \mathrm{H}_{2(g)}+2 \mathrm{OH}_{(a q)}^{-}
$$

Most of the waters from the semi-arid region of Northeast Brazil (namely Paraiba, Pernambuco and Ceará) require softening to a final calcium concentration of $60-70 \mathrm{mg} / \mathrm{L} \mathrm{CaCO}_{3}$ before discharge to a distribution system. During the drought period of the ninety decade of $16^{\text {th }}$ Century total hardness concentrations reached values in the range 300 to $1900 \mathrm{mg} / \mathrm{L} \mathrm{CaCO}_{3}$. Hence, extensive $\mathrm{CaCO}_{3}$ precipitation was observed causing a rapid reduction in the carrying capacity of the conduits. Also, because of the high chloride concentration with values above $5000 \mathrm{mg} / \mathrm{L} \mathrm{Cl}^{-}$and of the widespread use of metallic components in the water distribution networks (as, for instance, ironed conduits) corrosion is observed. The effects are brown-reddish waters, nodules formation and a progressive destruction of pipelines.

Thus a localized area of the cathode to which is highly insoluble mineral deposits fouling is created. The gaseous form of $\mathrm{H}^{+}$flows into the liquid surface silted (for flotation) hydroxides and suspended solids.

*Corresponding author: Agostinho LCL, Chemistry Department-CD/CST-UEPB, Rua Juvêncio Arruda, s/n-Bodocongó-CEP: 58.109-790, Campina Grande, Paraiba, Brazil; E-mail: cristina.uepb@gmail.com

Received July 18, 2012; Accepted September 27, 2012; Published October 01, 2012

Citation: Agostinho LCL, Nascimento L, Cavalcanti BF (2012) Water Hardness Removal for Industrial Use: Application of the Electrolysis Process. 1:460. doi:10.4172/scientificreports.460

Copyright: (c) 2012 Agostinho LCL, et al. This is an open-access article distributed under the terms of the Creative Commons Attribution License, which permits unrestricted use, distribution, and reproduction in any medium, provided the original author and source are credited. 


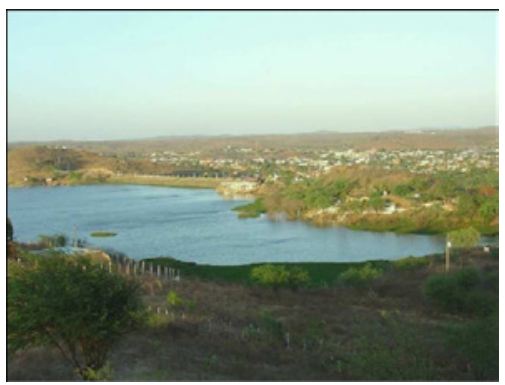

Figure 1: Spring representation of the weir Boqueirão-PB

This reduction produces an increase in hydroxyl ions. Considering this performance electrolysis proceeded to the level of research analyzing the performance of electrolysis "per se" and the combination of this process with chemical conditioning (dosing of chemicals) for softening of hard water. This article shows the results of this study for industrial use, namely, water softening to an $\mathrm{ILw}=0$ also given a total concentration of hardness ranging from 10 to $60 \mathrm{mg} / \mathrm{L} \mathrm{CaCO}$. Hard water used in the research was the distribution network of the city of Campina Grande, Paraíba. This water comes from the spring Boqueirão and treated (no slowdown) in the town of the same name situated about $50 \mathrm{~km}$ from Campina Grande, as represented in Figure 1.

\section{Theory}

\section{Brief review of lime-soda softening process}

Lime-soda process and the kinetics of magnesium precipitation were extensively studied by Loewenthal et al. [3]. From these studies, a conditioning diagram was developed termed Modified CaldwellLawrence diagram which allows calculating several chemical dosing. Six years later Friend and Loewenthal developed STASOFT, a software which allows, in a very simple and quick way, to apply the lime-soda process for softening waters with Total Dissolved Solids, TDS up to $15000 \mathrm{mg} / \mathrm{L}$. Briefly, the main considerations on this process are as follows:

Removal of magnesium ion from water is ruled by the solubility product of magnesium hydroxide, $\mathrm{k}_{\mathrm{spm}}$ (where $\mathrm{k}^{\prime}$ refers to activity influence on the solubility constant). Addition of softening substances such as a strong base or lime, $\mathrm{CaO}$ raises $\mathrm{pH}$ to such a value that it causes precipitation of magnesium hydroxide, $\mathrm{Mg}(\mathrm{OH})_{2}$. After precipitation the water reaches a particular state with respect to calcium carbonate.

According to Loewenthal and Marais [3], Total Alkalinity (in $\mathrm{CaCO}_{3}$ scale) is given by:

$$
\Delta A l k=-H_{(a d)}^{+}+\mathrm{HCO}_{3(a d)}^{-}+\mathrm{CO}_{3(a d)}^{2-}+\mathrm{OH}_{(a d)}^{-}
$$

where, "(ad)" means addition, $\Delta$ indicates change in concentration, $\mathrm{HCO}_{3}^{-}$and $\mathrm{CO}_{3}^{2-}$ are bicarbonate and carbonate species, respectively.

After lime addition, there is an immediate increase in $\mathrm{pH}$ and the change in alkalinity is equals to the amount which is precipitated. Thus:

$$
\Delta A l k=O H_{(a d)} ; A l k_{p p t}=O H_{p p t}^{-}
$$

where, ppt refers to precipitation.

Equal concentration of calcium and hydroxide ion are being added. Thus, the change in the difference between alkalinity and calcium is given by:

$$
C a_{(a d)}^{2+}=B H_{(a d)}^{+}
$$

$$
\begin{aligned}
& C a_{3(a d)}^{2-}=\Delta A l k=\Delta C a \\
& \Delta C 2=\Delta(A l k-C a)
\end{aligned}
$$

The water is then oversaturated with respect to $\mathrm{CaCO}_{3}$ and it precipitates with time.

The softening calculation is made as follows:

For lime calculation it is considered that each part of the precipitate removes a part of each magnesium and hydroxyl ion from solution.

The change in Acidity is given by:

$$
M g_{p p t}=O H_{p p t}^{-}=\Delta A C
$$

Acidity increase and lime dosage is determined as follows:

$$
C a O_{a d}=\triangle A C=\left(A c_{i}-A c_{f}\right)+M g O H_{2 p p t}
$$

Where "i" and "f" means initial and final parameter values, respectively.

After excess lime treatment, the water is scale forming and must be neutralized to remove caustic Alkalinity. Soda ash or $\mathrm{Na}_{2} \mathrm{CO}_{3}$ (sodium carbonate) is generally added to reduce calcium concentration and stabilize the water.

Addition of soda causes posterior precipitation of $\mathrm{CaCO}_{3}$ and the $\mathrm{Na}_{2} \mathrm{CO}_{3}$ dosage is determined as follows:

$$
\begin{aligned}
& \mathrm{CaO}_{a d}=\Delta \mathrm{Alk}-\mathrm{CO}_{3 p p t}^{2-}=\Delta(\mathrm{Alk}-\mathrm{Ca})=\Delta C 2 \\
& \mathrm{Na}_{2} \mathrm{CO}_{3(\text { ad })}=\Delta C 2=\left(C 2_{i}-C 2_{f}\right)
\end{aligned}
$$

As to Acidity, it remains unchanged. Post - stabilization is often required to decrease $\mathrm{pH}$ to a prefixed value by using $\mathrm{CO}_{2}$ addition (recarbonation) or strong acid addition. A Loewenthal Index of $+4 \mathrm{mg} / \mathrm{L}$ $\mathrm{CaCO}_{3}$ is applied to final water so that when it reaches the network system the water is just saturated with $\mathrm{CaCO}_{3}$.

\section{The electrolysis process}

The electrolysis process has been used for removal of a series of impurities, principally from wastewater [4-6]. In water treatment this process can be described as a combination of coagulation, flocculation, flotation and disinfection. The process shows significant effects for water purification such as colloid destabilization (colour removal), quick flocculation with the eroded material of the electrodes, electrochemical oxireduction reactions with oxygen and hydrogen ions which improve the removal of several industrial pollutants such as heavy metals, quick and strong oxidation. Also, it allows that the naturally chloride dissolved in raw water gives rise to chloride ions and to other antibacterial substances improving the disinfection process. As a water treatment process, electrolysis produces two forms of water: alkaline and reduced water and acidic or oxidized water. In the anode area, water is oxidized; i.e., the electrode metal is placed in solution in ionic form and occurs electron liberation of the metal. The $\mathrm{pH}$ is very low (below 3.0) and water becomes acidic. It is also observed a low concentration of dissolved oxygen. If water with sodium chloride is under electrolysis, a production of residual chloride ion is observed being the result of the oxidation process in solution. In the cathode, Alkalinity is established [7] and water is reduced. Thus, it becomes alkaline with $\mathrm{pH}$ values in the range 9.00-11.00. Water is reduced to hydrogen gas $\mathrm{H}_{2}$ and hydroxide ions, $\mathrm{OH}^{-}$at an electrode surface (cathode) thereby creating a localized area at the cathode that is highly insoluble to scale-forming mineral deposits. The observed $\mathrm{H}^{+}$reduction to gaseous form flows to the liquid surface carrying (by flotation) hydroxides and suspended solids. This 
Citation: Agostinho LCL, Nascimento L, Cavalcanti BF (2012) Water Hardness Removal for Industrial Use: Application of the Electrolysis Process. 1:460. doi:10.4172/scientificreports. 460

Page 3 of 5

(1) Anode

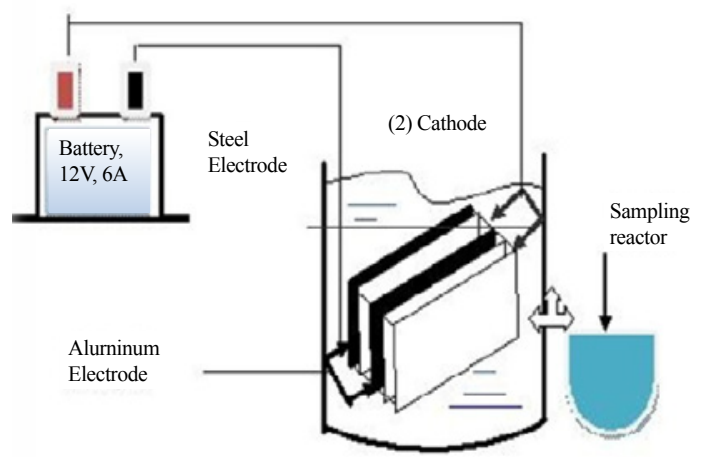

2 liters electrolysis reactor

Figure 2: Equipments used in laboratory scale for non carbonate hardness removal by using electrolysis.

\begin{tabular}{|l|c|}
\hline Parameter & Value \\
\hline TDS $(\mathrm{mg} / \mathrm{L})$ & 595,00 \\
\hline $\mathrm{pH}$ & 7,36 \\
\hline Alkalinity $\left(\mathrm{X}^{*}\right)$ & 100,00 \\
\hline Acidity $\left(\mathrm{X}^{*}\right)$ & 113,60 \\
\hline Conductivity, $(\mathrm{mS} / \mathrm{m})$ & 67,56 \\
\hline Total Hardness $\left(\mathrm{X}^{*}\right)$ & 355,00 \\
\hline Calcium $\left(\mathrm{X}^{*}\right)$ & 255,00 \\
\hline Magnesium $\left(\mathrm{X}^{*}\right)$ & 100,00 \\
\hline Chloride mg/L & 263,00 \\
\hline Loewenthal Index, Lwl & 1,8 \\
\hline lonic Strength & 0,011 \\
\hline
\end{tabular}

$\left(\mathrm{X}^{*}\right)=\mathrm{mg} / \mathrm{LCaCO}_{3}$

Table 1: Characteristics of tCG tap water at $28^{\circ} \mathrm{C}$

reduction produces an increase in hydroxyl ions, $\mathrm{OH}^{-}$. The ratification/ transformation unit of the reactor furnishes a continuous current of low voltage which circulates between the electrodes and, thus, propitiates the electrolysis.

\section{Electrolytical softening}

Generalities: The electrolysis process was applied to soften the hard water from the reticulation system of Campina Grande, Paraiba, Brazil. This water, here termed tCG, has the following chemical classification:"Low ionic strength water (Ionic strength calculated by using Langelier Equation given by $I=0,5^{\star} 10-5 T D S$ where TDS is in $\mathrm{mg} / \mathrm{L})$, chloride concentration adequate for public use but showing corrosiveness $(\mathrm{Cl}>50 \mathrm{mg} / \mathrm{L})$ and with predominance of permanent hardness or noncarbonated hardness".

The electrolytic station is showed in Figure 2 and is described as follows: A reactor of two liters was used in which was immersed an electrolyte cell made with two steel electrodes and two aluminum electrodes. Both had an area of $50 \mathrm{~cm}^{2}$, a thickness of $2 \mathrm{~mm}$ and are 0.5 $\mathrm{cm}$ far from each other. In the corner of the electrodes a $3 \mathrm{~mm}$ hole was made located $1 \mathrm{~cm}$ on the edges of the electrode. The end of a rigid wire was isolated in the small side of the electrode. This wire had $1.5 \mathrm{~mm}$ diameter and its length was $20 \mathrm{~cm}$. eight isolating spaces were made to ensure a good distance between the electrodes. They were interlinked with different polarities to a battery with $12 \mathrm{~V}$ and $36 \mathrm{~A}$ by means of flexible connecting wires.

The anode or sacrificed electrode (aluminum sheet) was connected to the cathode of the battery and the cathode (inox electrode) was connected to the anode of the battery.

The initial experiments were made by utilizing only tap water or tCG water. In the next experiments chemical dosing was applied using the following chemicals: Water A: $316 \mathrm{mg} / \mathrm{L} \mathrm{NaOH}$ (sodium hydroxide addition); Water (B): $310 \mathrm{mg} / \mathrm{L} \mathrm{NH}_{4} \mathrm{OH}$ (ammonium hydroxide addition) and Water (C): $270 \mathrm{mg} / \mathrm{L} \mathrm{CaO}$ (lime addition). In all experiments in the sedimentation tank a detention time was applied varying from 45 minutes to 2.00 hours.

\section{Results}

Table 1 shows the water quality of tap water from the reticulation system of Campina Grande, Paraiba State, Brazil. Table 2 shows the theoretical results of lime softening process applied to tCG tap water. Theoretical results after conditioning application; i.e. lime-soda softening are shown in Table 3 . The values were obtained by applying the STASOFT software [8], for terrestrial waters. These values can also be obtained by using the Modified Caldwell-Lawrence Diagram for ionic strength of 0.010 and temperature of $25^{\circ} \mathrm{C}$. It is also assumed that the water treatment for noncarbonated removal is accomplished before disinfection in 4.0 hours with the following times: (1) Mixing and flocculation in 30 minutes; (2) Sedimentation in 180 minutes and (3) Filtration in 30 minutes. Table 4 , shows the results of the electrolysis process application in tap water. These results were obtained without

\begin{tabular}{|l|c|}
\hline Parameter & Value \\
\hline TDS $(\mathrm{mg} / \mathrm{L})$ & 400,00 \\
\hline $\mathrm{pH}$ & 9,53 \\
\hline Alkalinity $\left(\mathrm{X}^{*}\right)$ & 30,00 \\
\hline Acidity $\left(\mathrm{X}^{*}\right)$ & 18,85 \\
\hline Conductivity, $(\mathrm{mS} / \mathrm{m})$ & 62,50 \\
\hline Total Hardness $\left(\mathrm{X}^{*}\right)$ & 10,00 \\
\hline Calcium $\left(\mathrm{X}^{*}\right)$ & 10,00 \\
\hline Magnesium $\left(\mathrm{X}^{\star}\right)$ & 0,00 \\
\hline Chloride mg/L & 263,00 \\
\hline Loewenthal Index, Lwl & 0,00 \\
\hline lonic Strength & 0,010 \\
\hline
\end{tabular}

$\left(X^{*}\right)=\mathrm{mg} / \mathrm{LCaCO}_{3}$

Table 2: Theoretical values for tCG water after lime addition.

\begin{tabular}{|l|c|}
\hline Parameter & Value \\
\hline TDS $(\mathrm{mg} / \mathrm{L})$ & 432,37 \\
\hline $\mathrm{pH}$ & 11,00 \\
\hline Alkalinity $\left(\mathrm{X}^{*}\right)$ & 67,30 \\
\hline Acidity $\left(\mathrm{X}^{*}\right)$ & $-86,50$ \\
\hline Conductivity,(mS/m) & 67,56 \\
\hline Total Hardness $\left(\mathrm{X}^{*}\right)$ & 10,00 \\
\hline Calcium $\left(\mathrm{X}^{*}\right)$ & 6,00 \\
\hline Magnesium $\left(\mathrm{X}^{*}\right)$ & 4,00 \\
\hline Chloride mg/L & 263,00 \\
\hline Loewenthal Index, Lwl & 0,00 \\
\hline Sodium, mg/L & 152,86 \\
\hline lonic Strength & 0,010 \\
\hline
\end{tabular}

$\left(X^{*}\right)=\mathrm{mg} / \mathrm{LCaCO}_{3}$

Table 3: Theoretical values for tCG water after chemical dosing with lime and soda 
Citation: Agostinho LCL, Nascimento L, Cavalcanti BF (2012) Water Hardness Removal for Industrial Use: Application of the Electrolysis Process. 1:460. doi: $10.4172 /$ scientificreports. 460

\begin{tabular}{|c|c|}
\hline Electrolysis time, et (min) & tcG water \\
\hline & TH, $\mathbf{~ m g / L C a C O}$ \\
\hline 0 & 355,00 \\
\hline 3 & 220,00 \\
\hline 10 & 180,00 \\
\hline 20 & 115,00 \\
\hline 30 & 70,00 \\
\hline 40 & - \\
\hline 50 & - \\
\hline
\end{tabular}

Table 4: Total Hardness values after electrolysis of tCG water.

\begin{tabular}{|c|c|c|c|}
\hline et(min)* & Water (A) & Water (B) & Water (C) \\
\hline & & & \\
\hline 0 & 355,00 & 355,00 & 355,00 \\
\hline 3 & 250,00 & 250,00 & 250,00 \\
\hline 10 & 100,00 & 135,00 & 200,00 \\
\hline 20 & 60,00 & 50,00 & 110,00 \\
\hline 30 & - & 35,00 & 90,00 \\
\hline 40 & - & - & 75,00 \\
\hline 50 & - & - & - \\
\hline
\end{tabular}

et $(\min )^{*}=$ electrolysis time

Table 5: Total Hardness results for Water (A): tcG plus ammonium hydroxide; Water (B): tCG plus sodium hydroxide and Water (C): tCG plus lime.

\begin{tabular}{|c|c|c|c|}
\hline et(min) $^{*}$ & Water (A) & Water (B) & Water (C) \\
\hline 0 & & & \\
\hline 3 & 7,36 & 7,36 & 7,36 \\
\hline 10 & 11,50 & 10,80 & 7,41 \\
\hline 20 & 11,30 & 11,00 & 8,28 \\
\hline 30 & 11,20 & 11,25 & 8,50 \\
\hline 40 & $\mathrm{~nm}$ & 11,15 & 8,62 \\
\hline 50 & $\mathrm{~nm}$ & $\mathrm{~nm}$ & 8,80 \\
\hline
\end{tabular}

Table 6: $\mathrm{pH}$ results for Water $(\mathrm{A})$ : tcG plus ammonium hydroxide; Water (B): tCG plus sodium hydroxide and Water (C): tCG plus lime.

chemical conditioning. Total Hardness removal valued with chemical conditioning and electrolysis are shown in Table 5. In next table, Table 6 , the $\mathrm{pH}$ results with chemical dosing and electrolysis can be seen. Figure 3 shows the noncarbonated hardness removal in water tCG and waters with chemical dosing versus electrolysis time. Finally, Figure 4 illustrates the results of the theoretical study performed in water tCG by applying conventional lime softening and lime-soda softening.

\section{Discussion}

In the anode of the electrolyte reactor it was observed the following reactions:

(1) The aluminum electrode was eroded and liberated trivalent aluminum, $\mathrm{Al}^{3+}$. This ion formed an ionic pair with sulphate of the tap water rich in magnesium sulphate. There was formation of aluminum sulphate which is a strong coagulant. An excellent flocculation and coagulation was observed and the process also lead to $80 \%$ hardness removal.

(2) Addition of alkalinizing chemicals allowed an increase in $\mathrm{pH}$ (although discrete when compared to the conventional lime softening process). Thus magnesium hydroxide formed in time has precipitated. It is important to state that the electrolysis process is able to provide the caustic to promote precipitation capture, retention and removal mechanisms. Concerning lime addition, its small dosage didn't increase $\mathrm{pH}$ significantly. However, it provided aged hardness removal.

(3) Liberated chloride ion, $\mathrm{Cl}^{-}$acts as a disinfectant. Although it was not performed any bacteriological sampling, it can be said that almost $100 \%$ removal of fecal coliforms removal is achieved after, at least, 30 minutes of electrolysis.

In the cathode the following reactions and phenomena were observed:

(1) Hydrogen ion was reduced to $\mathrm{H}_{2}$ gas which escaped to the liquid surface and carried suspended solids. Magnesium was flocculated and absorbed other suspended materials from water.

(2) The phenomena which govern the movement of the $\mathrm{Ca}^{2+}$ ion and $\mathrm{CO}_{3}^{2-}$ ion species toward the electrode are, mainly, ionic transport and electrochemical charge transfer reactions. These reactions occur at the electrode/solution interface.

(3) Both, electrical energy consumption and electrolytical erosion are small for this type of assemblage in the electrolytical reactor.

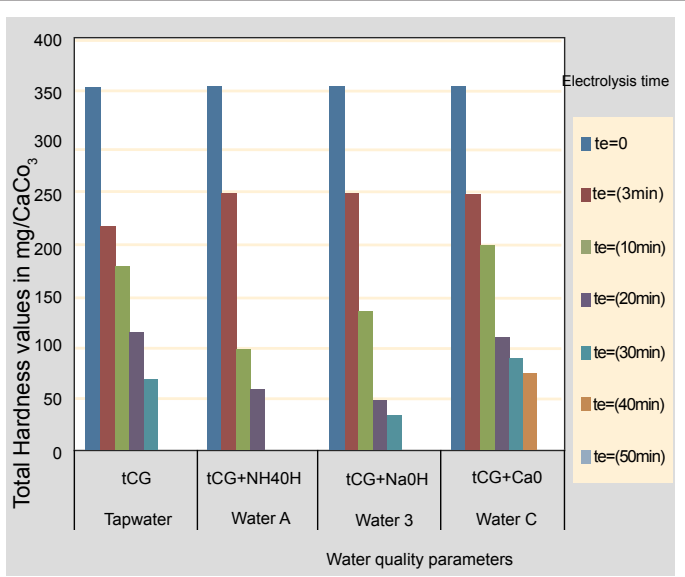

Figure 3: Noncarbonated hardness removal in tCG, Water A, Water B and Water $\mathrm{C}$, respectively, for industrial use.

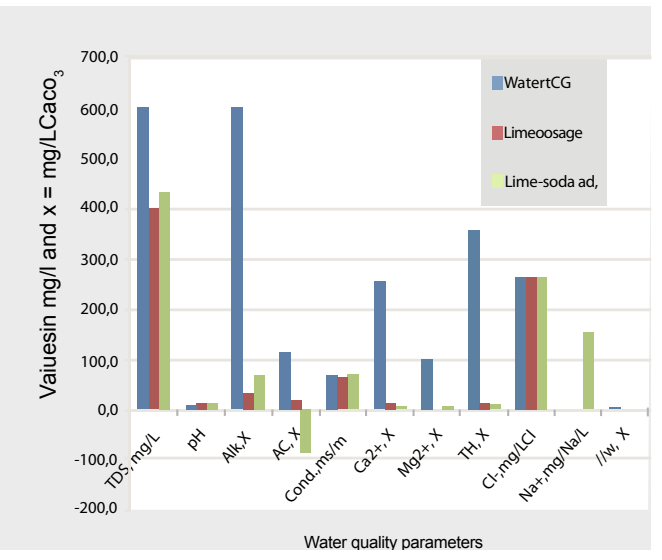

Figure 4: Results obtained from the application of electrolysis process in tCG water and theoretical values for lime softening and lime - soda softening for indust rial use. 
Citation: Agostinho LCL, Nascimento L, Cavalcanti BF (2012) Water Hardness Removal for Industrial Use: Application of the Electrolysis Process. 1:460. doi:10.4172/scientificreports. 460

Page 5 of 5

This is due, probably to the small distance between electrodes $(5 \mathrm{~mm})$. A smaller distance could, probably, lower the energy consumption (a lesser tension for the same current intensity). However, it should require some special cares of the daily cleanness applied on the electrodes.

(4) In the electrolytic process there can be no precipitation of organic and inorganic salts, which involve the consumption of $\mathrm{Ca}^{2+}$; it occurs when a chemical precipitation is preceded by electrocoagulation. The chemical coagulation process is the most widespread in the world for water treatment for potable purposes. The most commonly used coagulants in water treatment are aluminum salts and iron salts. The costs for the use of aluminum salts are inferior, but the iron salts have the advantage of being applied in a wider $\mathrm{pH}$ range.

\section{Conclusions}

The main conclusions are as follows:

The electrolysis process accelerated calcium carbonate precipitation. Then, it can be said that the process concentrates the scale-formation into the electrolysis reactor such that scale was reduced. Sodium hydroxide addition showed that sodium is attracted to cathode where hydroxyl ions are formed and this fact is due to electron liberation into water. The high $\mathrm{pH}$ value observed $(\mathrm{pH}=11.28)$ ensures a total magnesium precipitation. Also, it is formed albite; i.e, an aluminum and sodium silicate $\left(\mathrm{NaALSi}_{3} \mathrm{O}_{8(\mathrm{~s})}\right)$ that produces an excellent flotation. As a final conclusion, the electrolysis process for total hardness removal is not only of low cost but also it requires less time when compared to conventional water hardness removal process. For industrial use, this process allows to adjust hardness to values required to the particular industrial use.

\section{Acknowledgements}

The authors thank CNPq (National Counsel of Technological and Scientific Development) for financial support of this work.

\section{References}

1. Cavalcanti BF, Bonifacio N (1992) Modern Study of relaxation by lime-soda and post-stabilization of water ETA-Gravesend, PB, In: Proceedings ABES, 16th Brazilian Congress on Sanitary and Environmental Engineering, e II, Goiania.

2. Agostinho LCL, Nascimento L, Cavalcanti BF (2010) Tratamento de Águas Eutróficas Usando o Processo Eletrolítico. Engenhar ia Ambiental- Espírito Santo do Pinhal 7: 73-86.

3. loewenthal RE, Wieckers HNS, Marais GVR (1986) Softening and stabilization of municipal waters. Water Research Comission Report, Pretoria, South Africa.

4. Sandbank E, Shell G, Wachs AM (1974) Improved electroflotation for the removal of suspended solids from algal pond effluents. Water Research 8: 587 592.

5. Wiendl WG (2001) Electrolytic processes for the purification of sewage - A review secular ". DAE Magazine - SP 45: 50-54

6. Wiendl WG (2002) Electrolytic Processes in the Treatment of Sewage. Ed ABES. RJ.

7. Foyn E (1999) Chemical and biological aspects of sewage disposal in inner Oslo fjord, In: Proceedings $1^{\text {st }}$ International Conference on Waste Disposal in the Marine Environment. Univ. of Berkley, Ca, EUA.

8. Friend JFC, Loewenthal RE (1992) Chemical conditioning of low and medium salinity waters. Water Research Comission Report, Pretoria. 